\title{
Optimization of Pre-combustion Capture for Thermal Power Plants
}

\section{Using Pinch Analysis}

\author{
Saba Valiani ${ }^{1}$, Nassim Tahouni ${ }^{1 *}$, M. Hassan Panjeshahi ${ }^{1,2}$ \\ ${ }^{1}$ School of Chemical Engineering, College of Engineering, University of Tehran, Tehran, Iran \\ ${ }^{2}$ Department of Chemical and Petroleum Engineering, University of Calgary, Calgary, Alberta, Canada
}

\begin{abstract}
Carbon dioxide emissions from the chimneys of thermal power plants create major environmental risks. Therefore, an important step toward reducing the emissions in these power plants can be the carbon dioxide pre-combustion capture process. In this paper, a 150 megawatt thermal steam cycle power plant fueled by bagasse was studied. The power plant has an efficiency of $32.74 \%$, and emits $246.52 \mathrm{t} / \mathrm{h}$ carbon dioxide. First, the design and simulation of a suggested pre-combustion carbon dioxide capture process was outperformed. In this process, the amount of carbon dioxide separation and capture using mono ethanol amine (MEA) 30wt\% as solvent is $90 \%$. In this condition, the mass flow of bagasse was increased about $60 \%$ to keep the plant efficiency constant. At the same time, the energy loss as a result of the addition of the carbon dioxide recovery unit was around $11 \%$. The process was optimized through Pinch Analysis to reduce energy waste and fuel flow. Moreover, it was indicated that power plant efficiency could be increased around $8 \%$ by integrating the hot exhaust gases from the gasification unit with power plant boiler using a heat recovery steam generation (HRSG) unit. With this modification, bagasse consumption was decreased by $23 \%$.
\end{abstract}

Key words: Pre-combustion capture, Steam cycle power plants, Optimization, Pinch Analysis

* Corresponding author. Emailntahuni@ut.ac.ir 


\section{Introduction}

One of the most important issues facing researchers today, leading to significant global climate change is greenhouse gas emission to the atmosphere. Carbon dioxide $\left(\mathrm{CO}_{2}\right)$ is the most significant anthropogenic greenhouse gas, arising mainly out of power generation. Carbon dioxide capture and storage (CCS) is one of the measures required for the reduction of $\mathrm{CO}_{2}$ emission. $\mathrm{CO}_{2}$ capture processes can be divided into three general categories: (1) Post combustion capture, (2) oxy-fuel combustion, and (3) pre-combustion capture [1]. Many processes are available for separating carbon dioxide from gas mixtures based on physical absorption, chemical absorption, adsorption, membrane processes, etc. In the standard absorption process, flue gas in the absorber contacts with the lean solvent. The $\mathrm{CO}_{2}$ is absorbed by the solvent, which is sent to the stripper and heated there to release the $\mathrm{CO}_{2}$. Finally, the regenerated solvent is re-cycled to the absorber [2].

Several studies have indicated that high selectivity can be reached with absorption processes using chemical solvents, with the result being the increased production of pure $\mathrm{CO}_{2}$ [3]. Davidson [4] and Kothandaraman et al. [5] reported that recovery of carbon dioxide using chemical solvents was more practical. Comparing different solvents, they found that Mono Ethanol Amin is the best for carbon dioxide separation in terms of energy consumption and Techno-Economics. Addition of CCS processes to power plants increases the energy loss, reducing the produced net power by 10 to $15 \%$ [6]. In 2011, Kunze et al. [7] conducted a study using exergy analysis on an integrated gasification combined cycle (IGCC) power plant with a CCS unit, and found that much of the energy was wasted in the gasification unit. The energy loss caused by the addition of a CCS unit could be reduced by the employment of various methods. 
In the processes where solvents were used to absorb gas, the energy required for solvent recovery could be reduced by changing the type of solvent [8].

It is worth saying the total energy requirement in the reboiler can be reduced by improving the design of the solvent recovery unit. Besides, the use of the heat generated by CCS process in the steam cycle can contribute to the decreased energy loss resulting from CCS unit [9]. Romeo et al. [10] suggested that the optimal method is to extract saturated steam midway through the lowpressure section of the turbine. In this method, the lowest quality steam is used to meet the reboiler requirements. Additionally, Mimora et al. [11] used 14\% of the heat generated in the condenser of the stripper to heat the inlet water of boiler feed water.

Pfaff et al. [12] studied the usage of heat lost from the desorber overhead condenser and from the $\mathrm{CO}_{2}$ compressor into the boiler feed water. They also studied the number of coolers required among $\mathrm{CO}_{2}$ compressors for optimisation and use of the heat losses of these coolers in the steam cycle. Duan et al. [13] suggested the use of the heat of outlet gases from the regeneration process, and the heat recovered from a carbon dioxide compressing unit. Pinch Analysis is a practical method in optimizing CCS process. This method determines the minimum energy required by a process through maximizing the heat recovery of the process [14]. Besides, solvent regeneration needs a considerable amount of heat, provided by extracting steam from lowpressure turbines and exhaust steam [15]. Harkin et al. [14, 16] used Pinch Analysis and heat integration combined with linear programming to reduce energy losses in a base power plant with pre- and post- combustion capture. Bernier et al. [17] used multi-objective optimization to optimize natural gas combined cycle (NGCC) with post combustion capture. Khalilpour et al. [18] investigated Pinch Analysis to reduce the energy penalty from $19 \%$ to $15.4 \%$ of solvent- 
based post-combustion carbon capture processes. In similar studies, Leng et al. [19] used Pinch Analysis to reduce the waste energy from $17.6 \%$ to $12.3 \%$.

This study is aimed at designing pre-combustion capture unit for a $150 \mathrm{MWe}$ power plant fuelled by biomass. This process is also, optimized using Pinch Analysis and heat exchanger network (HEN) optimization to reduce not only carbon dioxide emission but also heat waste caused by adding CCS to power plant. To achieve the goal, three kinds of studies were conducted; first is base case steam cycle power plant without $\mathrm{CO}_{2}$ capturing, second is integration of base case power plant with pre-combustion capture unit, and third is optimization of heat exchanger network.

\section{Base case: Biomass power plant}

A $150 \mathrm{MWe}$ biomass thermal steam cycle power plant with an efficiency of $32.74 \%$ is considered as the basis consisting of four parts. Reboiler, as the first part of the unit, is used to convert energy and evaporate water. The temperature and pressure of outlet steam from the reboiler are $540^{\circ} \mathrm{C}$ and 126 bar, respectively. The steam quantity is about $525 \mathrm{t} / \mathrm{h}$ while the plant is working in high performance. There are 3 co-axial turbines, including a high-pressure turbine with one blend, a medium-pressure turbine with three blends, and a low-pressure turbine with one blend. The outlet steam from the high-pressure turbine becomes warmer in boiler before entering to the medium-pressure turbine. The turbines have a bypass route consisting of high-pressure and lowpressure valves, which can pass the outlet steam to the direct air condenser. In this type of condenser, the outlet steam from low-pressure turbine, which is under vacuum, is entered to the air condenser directly and is cooled down by 30 fans and is ultimately converted to the saturated water. The saturated water is entered to a condensate tank and is pumped to the water steam cycle. The schematic of the process is shown in Fig. 1. 
Fig. 1. Base case steam cycle power plant scheme

\subsection{Biomass analysis}

Sugarcane bagasse which is the sugarcane residue after sugar extraction is a resource of papermaking lignocellulosic fibers. This material has been used as fuel in some developing countries. Sugarcane bagasse is produced at an approximate rate of 4.3Mt/y in Iran [20]. The information of consumed bagasse as fuel for boiler is presented in Table 1. This data has been extracted from the database of Thermoflow Software, as confirmed by the experimental data of sugarcane production companies.

Table 1. Ultimate and proximate analysis of sugarcane bagasse

\subsection{Simulation of power plant}

The simulation of base case was done by Thermoflow Software, which is thermal engineering software applied to power generation industries. The mass flow rate for inlet bagasse to the boiler is $27 \mathrm{~kg} / \mathrm{s}$. According to the power plant practical information, high-pressure turbine has a blend with $5.92 \%$ of inlet steam. The steam is entered into the high-pressure feed water heater to heat water. As mentioned above, the medium-pressure turbine has three blends containing $16.89 \%$ of inlet steam to the turbine. One of the blends is entered into high-pressure feed water heater. The second and the third ones are entered into the deaerator and low-pressure feed water heater, respectively. The blend of low-pressure turbine, which contains $4.46 \%$ of the inlet steam of this turbine, is entered into low-pressure feed water heater. The simulation via Thermoflow Software has been shown in Figure 2.

Fig. 2. Power plant simulation via Thermoflow Software

Operational data such as temperature and pressure of turbines inlet/outlet streams, information of incoming/outgoing streams of pre-water heaters, boiler data, etc., extracted from a 150-megawatt 
steam cycle power plant working in IRAN was entered to software as input data. All data have been shown in Figure 1. The results of simulation such as net and gross power output, net and gross efficiency, and the amount of exhaust $\mathrm{CO}_{2}$ are presented in Table 2.

Table 2. Simulated operating parameters for steam cycle

\section{Case 2: Power plant with pre-combustion capture unit}

In this case, a pre-combustion capture unit was designed for the bagasse steam cycle power plant. In $\mathrm{CO}_{2}$ capture unit, bagasse is dried first and then entered to gasification unit for conversion to synthesis gas in the presence of $\mathrm{O}_{2}$. The cooled synthesis gas is converted to $\mathrm{CO}_{2}$ in the reactors. In these reactors, $\mathrm{CO}_{2}$ and $\mathrm{H}_{2}$ are produced as a result of the reaction between $\mathrm{CO}$ and water according to exothermic water gas shift reactor (WGSR) equilibrium reaction. In this study, mono-ethanol amine is used for gas adsorption. Therefore, to reach pure $\mathrm{H}_{2}$ as the power plant fuel, the outlet gases from the reactors move to absorption column so that $\mathrm{CO}_{2}$ is removed using absorbent. The schematic of this process is indicated in Fig. 3.

\subsection{Simulation of gasification and WGSR unit}

Aspen plus Software with Peng-Robinson thermodynamics model is used to simulate both gasification and WGSR unit. For mainly real non-polar components, like those in hydrocarbon processing, Peng-Robinson (PR) is recommended by Aspen Technology [21].

In general, the gasification process has been simulated in two steps: The first step is decomposition of dry bagasse fuel (with a moisture of about 10\%) and conversion of it into volatile components and ash. At this step, the yield distribution of volatile components production with regard to the ultimate and proximate analysis of fuel is determined. The second step consists of partial oxidation of gasification reactions simulated using Gibbs reactor model. Gibbs reactor model is based on the assumption that the Gibbs free energy of a chemical 
equilibrium system is at its minimum. The assumptions considered in the simulation of this unit using Aspen plus Software are as follows:

1. The system is iso-thermal and is in steady state.

2. Ash is considered as an inert component and does not participate in chemical reactions.

3. All sulfur in feed is converted into $\mathrm{H}_{2} \mathrm{~S}, \mathrm{NH}_{3}$ will be produced by nitrogen compounds and no nitrogen oxide exists in the product.

4. Tar and other heavy hydrocarbons are omitted as Gibbs reactor is used for modeling the gasification reaction. It should be noted that these components are products of nonequilibrium reactions [22].

Fig. 3. Power plant with pre-combustion capture unit scheme

In partial oxidation of gasification reactions, temperature and pressure of process as well as the amount of oxidant should be selected properly for incomplete combustion so that a proper synthesis gas composition is achieved. The temperature and pressure can be $800-1800{ }^{\circ} \mathrm{C}$ and 10-100 bar, respectively [23].

WGSR unit has both high temperature shift (HTS) and low temperature shift (LTS) reactors which work at $310-450{ }^{\circ} \mathrm{C}$ and $200-300{ }^{\circ} \mathrm{C}$, respectively [24]. Therefore, a cooler is contrived before each reactor to adjust the temperature of inlet gasses to the reactors. The schematic of this process is illustrated in Fig. 4.

\subsection{Simulation of carbon capture and storage unit}

After dehydration, WGSR gas outlet is entered to the absorption column from the bottom and while ascending, it contacts with amine solvent (30\% wt.) entered from some trays in the column. Up to $90 \%$ of the $\mathrm{CO}_{2}$ is removed from the gas in this process. The treated gas which mainly contains pure hydrogen is extracted from the top of the column and is used as clean fuel 
in power plants. The used amine exits from the bottom and is transferred to desorption column for recovery. Aspen Plus Software with ELECNRTL thermodynamics model is used to model carbon capture and storage unit. Some of the important data used or resulted is presented in Table 3. Some of the constraints for simulating this unit include: more than $90 \% \mathrm{CO}_{2}$ adsorption from the adsorption column inlet gas, $95 \%$ purification for outlet $\mathrm{CO}_{2}$ from desorption column and consumption of less than $4 \mathrm{GJ} / \mathrm{t} \mathrm{CO} \mathrm{C}_{2}$ energy in the reboiler.

Rich $\mathrm{CO}_{2}$ stream outlet from top of desorption column is entered to the compressor and is compressed up to 100 bar in four steps to be prepared for transportation and storage. To avoid condensation, coolers are put between any two compressing steps to cool down the gas (Fig. 4).

Fig. 4. Pre-combustion capture process

Table 3. Operating conditions of the $30 \mathrm{wt} \%$ MEA carbon capture unit When $\mathrm{CO}_{2}$ recovery unit is added to the process, energy penalty is about $11.4 \%$, which mainly results from using energy in $\mathrm{CO}_{2}$ compression unit. This value has been calculated by Eq.(1), suggested by Harkin et al [14].

$$
\text { Energy Penalty } \quad \Delta \mathrm{E}=1-\left(\eta_{\mathrm{CCS}} / \eta_{\text {Ref }}\right)
$$

where, $\eta_{\text {Ref }}$ and $\eta_{c c s}$ refer to base case power plant efficiency and power plant efficiency with CCS unit, respectively. The modeling results are given in Table 4.

Table 4. Plant performance of case 2 


\section{Case 3: Heat integration of base case power plant with pre-combustion capture}

The process was optimized in this part using Pinch Analysis. Moreover, the hot exhaust gases from the gasification unit were integrated with power plant boiler using a heat recovery steam generation (HRSG) unit. The cost of pre-combustion capture unit was estimated as well.

\subsection{Heat integration through pre-combustion capture unit}

When a carbon dioxide recovery unit is added to the existing power plant, some cold and hot streams are added to the system as well. As illustrated in Fig. 4, the hot streams of the current system may include HTS outlet stream $\left(\mathrm{H}_{1}\right)$, LTS outlet stream $\left(\mathrm{H}_{2}\right)$, solvent-rich outlet stream from bottom of the desorption column $\left(\mathrm{H}_{3}\right)$, the gasification unit outlet stream $\left(\mathrm{H}_{4}\right), \mathrm{CO}_{2}$-rich stream outlet from the top of the desorber column $\left(\mathrm{H}_{5}\right)$, and hot streams that must be cooled in the intercoolers stages of $\mathrm{CO}_{2}$ compressing unit $\left(\mathrm{H}_{6}, \mathrm{H}_{7}, \mathrm{H}_{8}\right)$. The cold streams may include the outflow from the bottom of the absorption column $\left(\mathrm{C}_{1}\right)$ and the inlet cold stream to the reboiler of desorption column $\left(\mathrm{C}_{2}\right)$. Complete information about these hot and cold streams is indicated in Table 5. All data shown in Table 5 are obtained from simulation results. The data required for Pinch Analysis involves process stream heating and cooling information, utility stream information, and cost information. It should be noted that Heat Capacity Flow rate, shown in Table 5, is stream mass flow rate multiplied by specific heat capacity $(\mathrm{mCp})$.

Table 5. Hot and cold streams information of CCS unit

As indicated in Table 5, the hot streams $\mathrm{H}_{5}, \mathrm{H}_{6}, \mathrm{H}_{7}$ and $\mathrm{H}_{8}$ have lower enthalpy than the other hot streams, and the hot stream from gasification reactor $\left(\mathrm{H}_{4}\right)$ has a very high temperature and thermal load which can be used in the power plant. Therefore, they have been neglected in the design of CCS unit heat exchangers network, where three hot $\left(\mathrm{H}_{1}, \mathrm{H}_{2}\right.$ and $\left.\mathrm{H}_{3}\right)$ and two cold streams $\left(\mathrm{C}_{1}\right.$ and $\left.\mathrm{C}_{2}\right)$ are considered. 
The costs of the hot and cold utilities as well as the cost of heat exchangers are needed for economic calculation. According to local prices, the cost of high pressure steam utilities is $11 \$ / \mathrm{t}$ of steam. Thus, the cost of hot utilities is obtained $102 \$ / \mathrm{kW} . \mathrm{y}$. The cold utility service cost which was provided by local price data, was $18 \$ / \mathrm{kW} . \mathrm{y}$. Heat exchangers price is a function of their area which is defined by Eq. (2).

$$
\text { Exchanger Cost }=a_{e x}+b_{e x} A_{e x}^{c_{e x}}
$$

where $A_{e x}$ is the area of the heat exchanger, $a_{e x}$ is heat exchanger installation cost, and $b_{e x}$ and $c_{e x}$ are functions of heat exchanger material.

These parameters are determined by a non- linear regression of heat exchanger costs in terms of heat exchangers areas. The parameters for one heat exchanger are available in Table 6 and the results of these calculations are shown in Table 7.

Table 6. Results of regression for cost equation

Next, all data related to available hot, and cold streams including hot and cold utilities as well as cost data are imported to PILOT Software [25]. Having completed the stream data, physical property data and cost data, a range targeting of Total Annualized Cost (TAC) is conducted at different minimum temperature approaches $(\Delta \mathrm{Tmin})$. The TAC is the summation of energy cost and investment cost. Using these utility and investment costs, $\Delta \mathrm{Tmin}=4^{\circ} \mathrm{C}$ was found as target value, where the TAC has minimum value, shown in Fig. 5. However, this $\Delta$ Tmin just matches plate-fin heat exchangers. In case shell and tube heat exchangers are used, the $\Delta$ Tmin should be at least $10^{\circ} \mathrm{C}$. Although the optimum $\Delta \mathrm{Tmin}$ has been achieved at $4^{\circ} \mathrm{C}$ according to Figure 5 , the design of heat exchanger network should be carried out at $10{ }^{\circ} \mathrm{C}$ using pinch design method (PDM). Fig. $6 \mathrm{a}$ indicates composite curves at $\Delta \mathrm{T}_{\min }=10{ }^{\circ} \mathrm{C}$. The hot and cold temperatures of the pinch as well as the minimum of cold and hot utilities are specified in these diagrams. 
Fig. 5. Total annual costs versus different $\Delta \mathrm{T}_{\min }$

Fig. 6. a) Hot and Cold Composite Curve for pre-combustion capture process at $\Delta \mathrm{T}_{\min }=10{ }^{\circ} \mathrm{C}$

b) Grand Composite Curve for pre combustion capture process in $\Delta \mathrm{T}_{\min }=10{ }^{\circ} \mathrm{C}$

Pinch analysis is a systematic procedure that enables us to target minimum requirements of energy and heat exchanger network area and achieve the target values in design step of a process [26]. The design of heat recovery networks is generally carried out in two stages. First, there is a targeting stage in which the economics of heat recovery are evaluated in order to set the recovery level. This involves a trading-off between energy and network capital costs. The second stage involves network synthesis. Here, the topology of the heat recovery system required to realize the targeted energy recovery is specified [27].

Having used graphical representations of the process via simple diagrams as composite curves and grand composite curve (GCC), the maximum energy transfer from hot streams (streams that are to be cooled) to cold streams (streams that are to be heated) is maximized. Therefore, minimum utility requirements can be determined from composite curves which are based on a specific $\Delta \mathrm{T}_{\min }$ between the hot and cold streams (see Fig. 6a). The GCC indicated in Fig. 6b is based on the same stream data as used in the composite curves, but serves better to implying the interface between the process and utility system. The GCC provides the same overall energy target as provided by the composite curves. The summary of energy and area targeting at $\Delta \mathrm{T}_{\min }=10^{\circ} \mathrm{C}$ is shown in Table 7.

Table 7. Results of area and utility targeting

Next, using PDM, heat exchanger network of pre-combustion capture unit was separately designed for above and below the pinch point to avoid heat transferring across the pinch. The networks shown in Figs. 7 and 8, where $\mathrm{H}_{1}, \mathrm{H}_{2}$ and $\mathrm{H}_{3}$ are hot streams and $\mathrm{C}_{1}$ and $\mathrm{C}_{2}$ are cold 
streams. The temperature of each stream is shown in ${ }^{\circ} \mathrm{C}$ on top of the streams, and the heat load of heat exchangers is shown in MW under the heat exchangers. Finally, the HENs are merged to show the completed design in Fig. 9. Meanwhile, Table 8 indicates the comparison between targeting and design results.

Fig. 7. HEN design for above the pinch section using PDM

Fig. 8. HEN design for below the pinch section using PDM

Fig. 9. Heat exchanger network design for pre-combustion capture process using PDM

Table 8. Comparison between targeted and designed value of utility and area

\subsection{Using HRSG unit to reduce the power plant boiler heat loading}

The outlet gas from gasification reactor which was neglected in section 4.1 , has released an energy of about $116 \mathrm{MW}$ in cooler to reach $138.5^{\circ} \mathrm{C}$ from $400{ }^{\circ} \mathrm{C}$ (Fig. 4). As an opportunity considered in this study, this thermal energy can be used to convert boiler feed water to steam which leads to lower boiler loading. Boiler load is calculated 458.09 MW taking into account the clean fuel mass flow entering the boiler and its higher heating value, and the efficiency of the power plant in this situation is $32.74 \%$.In order to decrease the boiler load by $116 \mathrm{MW}$, the mass flow rate of clean fuel should be decreased, which in turn requires a decrease in the mass flow rate of bagasse. On the other hand, as the mass flow rate decreases, heat of outlet hot gas from gasification reactor decreases to a value lower than $116.1 \mathrm{MW}$. Therefore, the bagasse mass flow rate and the boiler heat load that can be replaced in the boiler should be determined by using heat integration. So, it is concluded that with a $8.5 \mathrm{~kg} / \mathrm{s}$ decrease in the mass flow rate of bagasse. $29 \%$ of feed water in HRSG unit can be vaporized by using the thermal energy of hot gas coming from gasification reactor (Fig. 10). In this case, the efficiency of power plant increased by $8 \%$, meaning a saving in the fuel consumption.

Fig. 10. HRSG unit in power plant 
Fig. 11 depicts the pre-combustion capture unit with new heat exchangers and utilities obtained by designing the CCS. Hot and cold streams are shown in Fig. 11.

Fig. 11. Pre-combustion capture HEN optimization using Pinch Analysis

In the third case, by adding HRSG and using the heat of stream coming from the gasification unit, the mass flow rate of fuel was decreased by $7 \mathrm{~kg} / \mathrm{s}$, and the efficiency was enhanced by $8 \%$, which ultimately led to a 1.5 million $\$$ decrease in the annual cost. The results of HRSG and power plant cycle integration are available in Table 9.

Table 9. Comparison between power plant results before and after using HRSG unit

\section{Conclusion}

In this paper, we studied a 150-megawatt thermal power plant steam cycle, fueled by bagasse. The efficiency of the power plant was $32.74 \%$ and the emission of $\mathrm{CO}_{2}$ to the environment was $1.643 \mathrm{~kg} / \mathrm{kWh}$. The power plant simulation studies were divided into two parts; first one without and the second one with carbon di-oxide recovery unit. In the second one, carbon di-oxide was separated and adsorbed using MEA solvent $30 \%$ by weight. To reduce energy penalty caused by the addition of CCS unit and fuel consumption, the process was optimized using Pinch Analysis. Finally, by using the HRSG unit, the efficiency of the power plant was increased by $8 \%$, and the fuel consumption was decreased by $23 \%$. 


\section{Nomenclature}

\begin{tabular}{|ll|}
\hline$\Delta \mathrm{T}_{\text {min }}$ & Minimum Temperature Approach \\
$\mathrm{CCS}$ & Carbon Capture and Storage \\
$\mathrm{CO}_{2}$ & Carbon Dioxide \\
$\mathrm{GCC}$ & Grand Composite Curve \\
$\mathrm{HEN}$ & Heat Exchanger Network \\
$\mathrm{HHV}$ & High Heating Value \\
$\mathrm{HP}$ & High Pressure \\
$\mathrm{HRSG}$ & Heat Recovery Steam Generation \\
$\mathrm{HTS}$ & High Temperature Shift \\
$\mathrm{I}$ & Interest rate per year \\
$\mathrm{IGCC}$ & Integrated Gasification Combined Cycle \\
$\mathrm{IP}$ & Intermediate Pressure \\
LP & Low Pressure \\
LTS & Low Temperature Shift \\
MEA & Mono Ethanol Amine \\
$\mathrm{N}$ & Plant life time \\
$\eta_{\text {ccs }}$ & Power Plant Efficiency with CCS Unit \\
$\eta_{\text {Ref }}$ & Base Case Power Plant Efficiency \\
NGCC & Natural Gas Combined Cycle \\
PDM & Pinch Design Method \\
WGSR & Water Gas Shift Reactor \\
\hline
\end{tabular}

\section{Acknowledgment}

The authors would like to express their gratitude for financial support from Iran National Science Foundation throughout this research work.

\section{References}

[1] CO2 capture and storage, A key carbon abatement option. International Energy Agency (IEA). Paris; 2008.

[2] Harkin T, Hoadley A, Hooper B. Optimisation of power stations with carbon capture plants, the tradeoff between costs and net power. Journal of Cleaner Production 2012; 34: 98-109.

[3] Alie C, Douglas PL, Davison J. On the operability of power plants with $\mathrm{CO}_{2}$ capture and storage. 
Energy Procedia 2009; 1: 1521-26.

[4] Davison J. Performance and costs of power plants with capture and storage of $\mathrm{CO}_{2}$. Energy 2007; 32: $1163-76$.

[5] Kothandaraman A, Nord L, Bolland O, Herzog HJ, McRae GJ. Comparison of solvents for postcombustion capture of $\mathrm{CO}_{2}$ by chemical absorption. Energy Procedia 2009; 1: 1373-80.

[6] Harkin T, Hoadley A, Hooper B. Using multi-objective optimisation in the design of $\mathrm{CO}_{2}$ capture systems for retrofit to coal power station. Energy 2012; 41: 225-38.

[7] Kunze C, Riedl K, Spliethoff H. Structured exergy analysis of an integrated gasification combined cycle (IGCC) plant with carbon capture. Energy 2011; 36: 1480-87.

[8] Davidson RM. Post-combustion carbon capture from coal fired plants solvent scrubbing. Report in: IEA Clean Coal Centre; 2007.

[9] Liu G, Williams RH, Larson ED, Kreutz TG. Design/economics of low-carbon power generation from natural gas and biomass with synthetic fuels co-production, Energy Procedia Journal 2011; 4: 1989-96.

[10] Romeo LM, Bolea I, Jesus ME. Integration of power plant and amine scrubbing to reduce $\mathrm{CO}_{2}$ capture costs. Applied Thermal Engineering 2008; 28: 1039-46.

[11] Mimura T, Simayoshi H, Suda T, Iijima M. Development of energy saving technology for flue gas carbon dioxide recovery in power plant by chemical absorption method and steam system.1997; 38 .

[12] Pfaff I, Oexmann J, Kather A. Optimised integration of post-combustion $\mathrm{CO}_{2}$ capture process in greenfield power plants. Energy 2010; 35: 4030-41.

[13] Duan L, Zhao M, Yang Y. Integration and optimization study on the coal-fired power plant with $\mathrm{CO}_{2}$ capture using MEA. Energy 2012; 45: 107-16.

[14] Harkin T, Hoadley A, Hooper B. Reducing the energy penalty of $\mathrm{CO}_{2}$ capture and compression using pinch analysis. Journal of Cleaner Production 2010; 18: 857-66.

[15] Harkin T, Hoadley A, Hooper B. Process integration analysis of a brown coal-fired power station with $\mathrm{CO}_{2}$ capture and storage and lignite drying. Energy Procedia Journal 2009;1: 3817-25. 
[16] Harkin T, Hoadley A, Hooper B. Optimisation of pre-combustion capture for IGCC with a focus on the water balance, Energy Procedia Journal 2011; 4: 1176-83.

[17] Bernier E, Marechal F, Samson R. Multi-objective design optimization of a natural gas-combined cycle with carbon dioxide capture in a life cycle perspective. Energy 2010; 35: 1121-28.

[18] Khalilpour R, Abbas A. HEN optimization for efficient retrofitting of coal fired power plants with post combustion carbon capture. International Journal of Greenhouse Gas Control 2011; 5: 189-99.

[19] Leng W, Abbas A, Khalilpour R. Pinch analysis for integration of coal fired power plants with carbon capture. In: 20 ${ }^{\text {th }}$ European Symposium on Computer Aided Process Engineering (ESCAPE20). Elsevier; 2010.

[20] Hemmasi AH, Samariha A, Tabei A, Nemati M, Khakifirooz A. Study of morphological and chemical composition of fibers from Iranian sugarcane bagasse. In: American-Eurasian J. Agric. \& Environ. Sci. 2011; 11: 478-81.

[21] Nord LO, Pre-combustion $\mathrm{CO}_{2}$ capture: Analysis of integrated reforming combined cycle. Doctoral thesis for the degree of philosophiae doctor, Norwegian University of Science and Technology 2010; ISBN: 978-82-471-2126-9.

[22] Mavukwana A, Jalama K, Ntuli F, Harding K. Simulation of Sugarcane Bagasse Gasification using Aspen Plus. International Conference on Chemical and Environmental Engineering 2013.

[23] Lotric A, Sekavcnik M, Kunze C, Spliethoff H. Simulation of water gas shift membrane reactor for integrated gasification combined cycle plant with $\mathrm{CO}_{2}$ capture. Journal of Mechanical Engineering 2011; 57: $911-26$.

[24] Lima DFB, Zanella FA, Lenzi MK, Ndiaye PM. Modeling and simulation of water gas shift reactor: An industrial case. Petrochemicals; 2012. Dr Vivek Patel (Ed.), ISBN: 978-953-51-0411-7, In Tech, Available from: www.intechopen.com/books/petrochemicals/modeling-and-simulation-of-water-gasshift-reactors-an industrial-case.

[25] PILOT. Software for targeting and design of HEN. University of Tehran: Iran; 2010. 
[26] Azadi M, Tahouni N, Panjeshahi, MH. Energy conservation in methanol plant using CHP system. Applied Thermal Engineering 2016; 107, 1324-33.

[27] Panjeshahi MH, Tahouni N. Pressure drop optimisation in debottlenecking of heat exchanger networks. Energy 2008; 33, 942-51. 


\section{List of Figures}

Fig. 1. Base case steam cycle power plant scheme

Fig. 2. Power plant simulation via Thermoflow Software

Fig. 3. Power plant with pre-combustion capture unit scheme

Fig. 4. Pre-combustion capture process

Fig. 5. Total annual costs versus different $\Delta$ Tmin

Fig. 6. a) Hot and Cold Composite Curve for pre-combustion capture process in $\Delta \operatorname{Tmin}=4{ }^{\circ} \mathrm{C}$

b) Grand Composite Curve for pre combustion capture process in $\Delta \mathrm{Tmin}=4{ }^{\circ} \mathrm{C}$

Fig. 7. HEN design for above the pinch section using PDM

Fig. 8. HEN design for below the pinch section using PDM

Fig. 9. Heat exchanger network design for pre-combustion capture process using PDM

Fig. 10. HRSG unit in power plant

Fig. 11. Pre-combustion capture HEN optimization using Pinch Analysis 
Table 1. Ultimate and proximate analysis of sugarcane bagasse

\begin{tabular}{lrr}
\hline Component & Dry Basis (wt\%) & Wet Basis (wt\%) \\
\hline Ultimate analysis & 0 & 10.39 \\
Moisture & 2.44 & 2.19 \\
Ash & 48.64 & 43.59 \\
Carbon & 5.87 & 5.26 \\
Hydrogen & 0.156 & 0.14 \\
Nitrogen & 0 & 0.04 \\
Chlorine & 0.045 & 38.39 \\
Sulfur & 42.84 & 10.7 \\
Oxygen & & 10.39 \\
Proximate analysis & 0 & 2.19 \\
Moisture & & \\
Ash & 2.44 & \\
Volatile matter & 85.62 & \\
Fixed carbon & & \\
\hline
\end{tabular}


Table 2. Simulated operating parameters for steam cycle

Property

Simulation Value

Steam cycle

High Pressure (HP) steam temperature $\left({ }^{\circ} \mathrm{C}\right)$

HP steam pressure (bar)

126

Intermediate Pressure (IP) steam temperature $\left({ }^{\circ} \mathrm{C}\right)$

534

IP steam pressure (bar)

Low Pressure (LP) steam temperature $\left({ }^{\circ} \mathrm{C}\right)$

LP steam pressure (bar)

LP turbine outlet temperature $\left({ }^{\circ} \mathrm{C}\right)$

63.8

LP turbine outlet pressure (bar)

0.28

Steam extracted from HP turbine (\%)

5.92

Steam extracted from IP turbine (\%)

16.89

Steam extracted from LP turbine (\%)

4.46

\section{Overall power plant}

Gross power output (MWe)

Gross electrical efficiency $(\%)$

Gross heat rate $(\mathrm{kJ} / \mathrm{MWh})$

Net power output (MW)

Net electrical efficiency (\%)

Net heat rate $(\mathrm{kJ} / \mathrm{MWh})$

Net fuel input (High Heating Value (HHV)) (MW)

$\mathrm{CO}_{2}(\mathrm{t} / \mathrm{h})$

$\mathrm{CO}_{2}(\mathrm{~kg} / \mathrm{kWh})$ 
Table 3. Operating conditions of the $30 \mathrm{wt} \%$ MEA carbon capture unit

Absorber column

Equilibrium stages

Removal of $\mathrm{CO}_{2}(\%)$

Absorber bottoms loading ( $\mathrm{mol} \mathrm{CO} 2 / \mathrm{mol} \mathrm{MEA})$

0.37

Absorber temperature $\left({ }^{\circ} \mathrm{C}\right)$

Desorber column

Equilibrium stages

$\mathrm{CO}_{2}$ purity, stripper overhead (\%)

Reboiler duty $\left(\mathrm{GJ} / \mathrm{t} \mathrm{CO}_{2}\right)$

Reboiler duty (MW)

Desorber column temperature $\left({ }^{\circ} \mathrm{C}\right)$

133.27

Column pressure (bar) 
Table 4. Plant performance of case 2

$\begin{array}{ll}\text { Parameter } & \text { Value }\end{array}$

Gross power of plant with pre-combustion capture unit (MW) 150

Power of CCS auxiliary ( compressors, pumps, etc) (MW) 17.61

Gross electrical efficiency of power plant with CCS unit (case study 2) (\%) 29

$\begin{array}{ll}\text { Energy penalty (\%) } & 11.4\end{array}$

$\begin{array}{lr}\mathrm{CO}_{2} \text { emitted }(\mathrm{kg} / \mathrm{kWh}) & 0.0639\end{array}$ 
Table 5. Hot and cold streams information of CCS unit

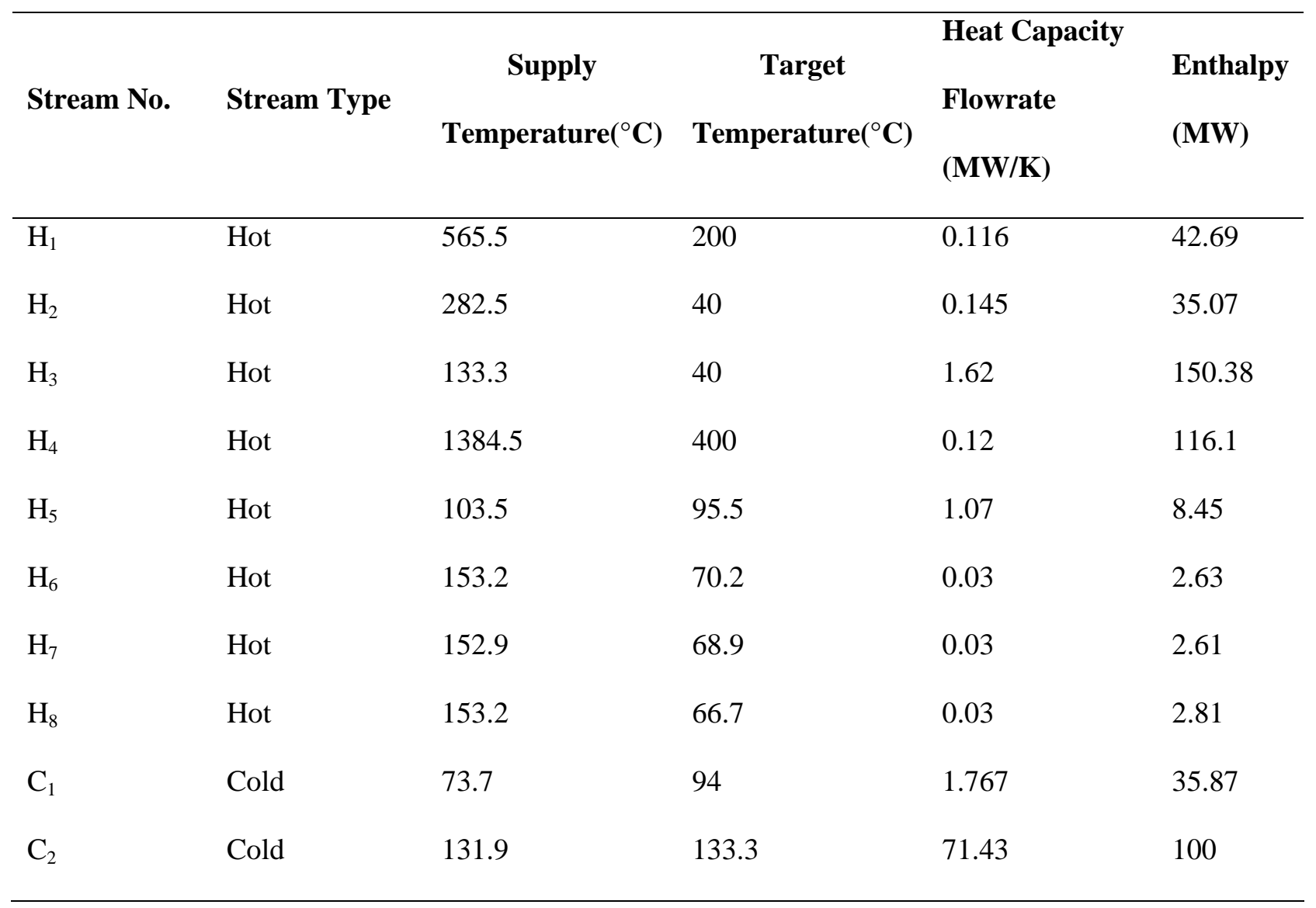


Table 6. Results of regression for cost equation

\begin{tabular}{lr}
\hline Parameters & Shell and Tube Heat Exchangers \\
\hline & Carbon Steel \\
$\mathrm{a}_{\mathrm{ex}}$ & $1667.58 \$$ \\
$\mathrm{~b}_{\mathrm{ex}}$ & $359.4 \$$ \\
$\mathrm{c}_{\mathrm{ex}}$ & 0.97 \\
\hline
\end{tabular}


Table 7. Results of area and utility targeting

\begin{tabular}{ll}
\hline Parameters (@ $\left.\Delta \mathrm{T}_{\min }=10{ }^{\circ} \mathrm{C}\right)$ & Value
\end{tabular}

Hot temperature of pinch $\left(\mathrm{T}_{\mathrm{H} \text { Pinch }}\right)\left({ }^{\circ} \mathrm{C}\right) \quad 131.9$

Cold temperature of pinch $\left(\mathrm{T}_{\mathrm{C} \text { Pinch }}\right)\left({ }^{\circ} \mathrm{C}\right) \quad 141.9$

$\begin{array}{ll}\text { Minimum area }\left(\mathrm{m}^{2}\right) & 6402.75\end{array}$

Minimum number of units $(\mathrm{N}) \quad 6$

Minimum hot utility (MW) $\quad 36.979$

Minimum cold utility (MW) $\quad 129.245$

Hot utility cost (million \$/y) 3.77

Cold utility cost (million \$/y) 2.33

Area cost (million \$) $\quad 1.876$

$\begin{array}{ll}\text { Interest rate per year (i) } & 0.15\end{array}$

Plant life time (n) (y) 5

$\begin{array}{ll}\text { Annualisation factor }=\frac{i(1+i)^{n}}{(1+i)^{n}-1} & 0.298\end{array}$

$\begin{array}{ll}\text { Area cost (million } \$ / y) & 0.559\end{array}$ 
Table 8. Comparison between targeted and designed value of utility and area

\begin{tabular}{lrrr}
\hline Parameter & Target & Design & Penalty (\%) \\
\hline Minimum hot utility (MW) & 36.9 & 36.9 & 0 \\
Minimum cold utility (MW) & 129.25 & 129.25 & 0 \\
Minimum area $\left(\mathrm{m}^{2}\right)$ & 6402.75 & 7465.34 & 17 \\
\hline
\end{tabular}


Table 9. Comparison between power plant results before and after using HRSG unit

\begin{tabular}{|c|c|c|}
\hline Parameters & $\begin{array}{l}\text { Before Using } \\
\text { HRSG Unit } \\
\text { (case 2) }\end{array}$ & $\begin{array}{c}\text { After Using } \\
\text { HRSG Unit } \\
\text { (case 3) }\end{array}$ \\
\hline Input bagasse flow rate to gasification reactor $(\mathrm{kg} / \mathrm{s})$ & 43.94 & 35.5 \\
\hline Boiler feed water flow rate $(\mathrm{kg} / \mathrm{s})$ & 137.5 & 98.25 \\
\hline Input treated gas flow rate to boiler $(\mathrm{kg} / \mathrm{s})$ & 4.69 & 3.13 \\
\hline Hot gas heating value (MW) & 116.1 & 93.7 \\
\hline Boiler heating value (MW) & 458.09 & 364.7 \\
\hline Power plant efficiency $(\%)$ & 32.74 & 41 \\
\hline
\end{tabular}




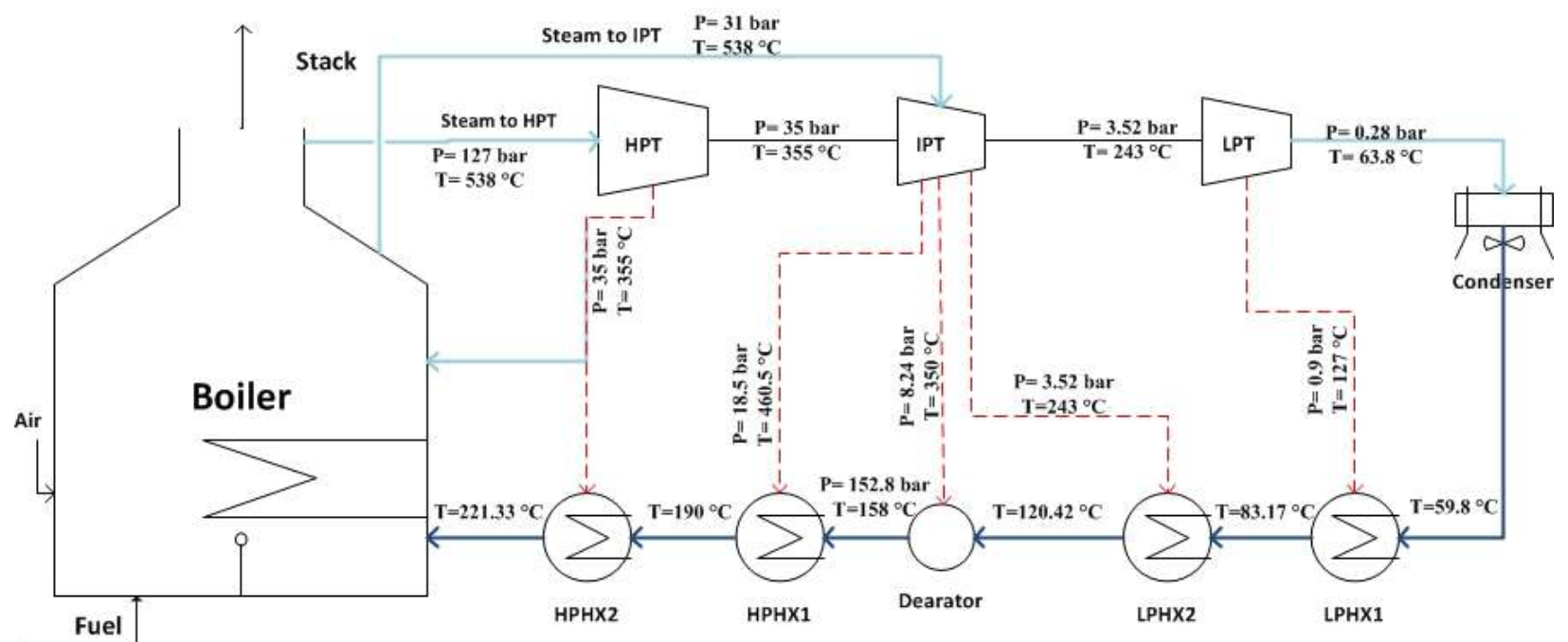

HPT: High Pressure Turbine

IPT: Intermediate Pressure Turbine

LPT: Low Pressure Turbine

HPHX: High Pressure Heat Exchanger

LPHX: Low Pressure Heat Exchanger

Fig. 1. Base case steam cycle power plant scheme

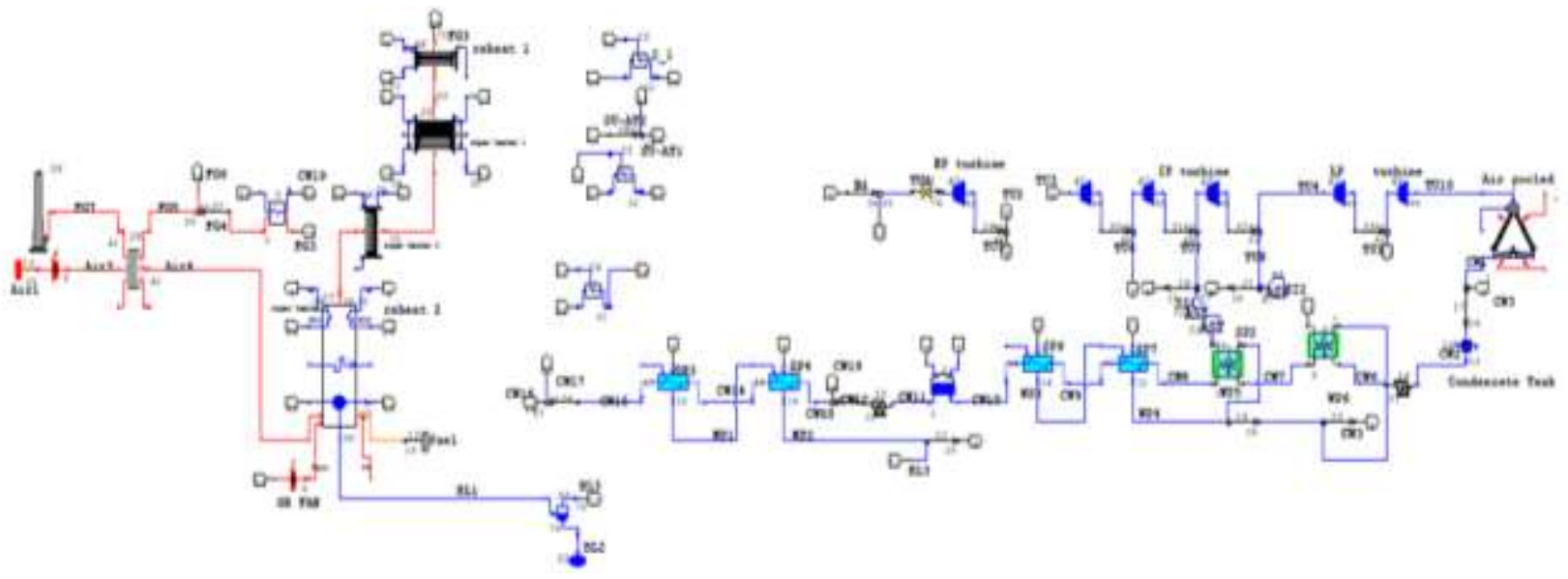

Fig. 2. Power plant simulation via Thermoflow Software 


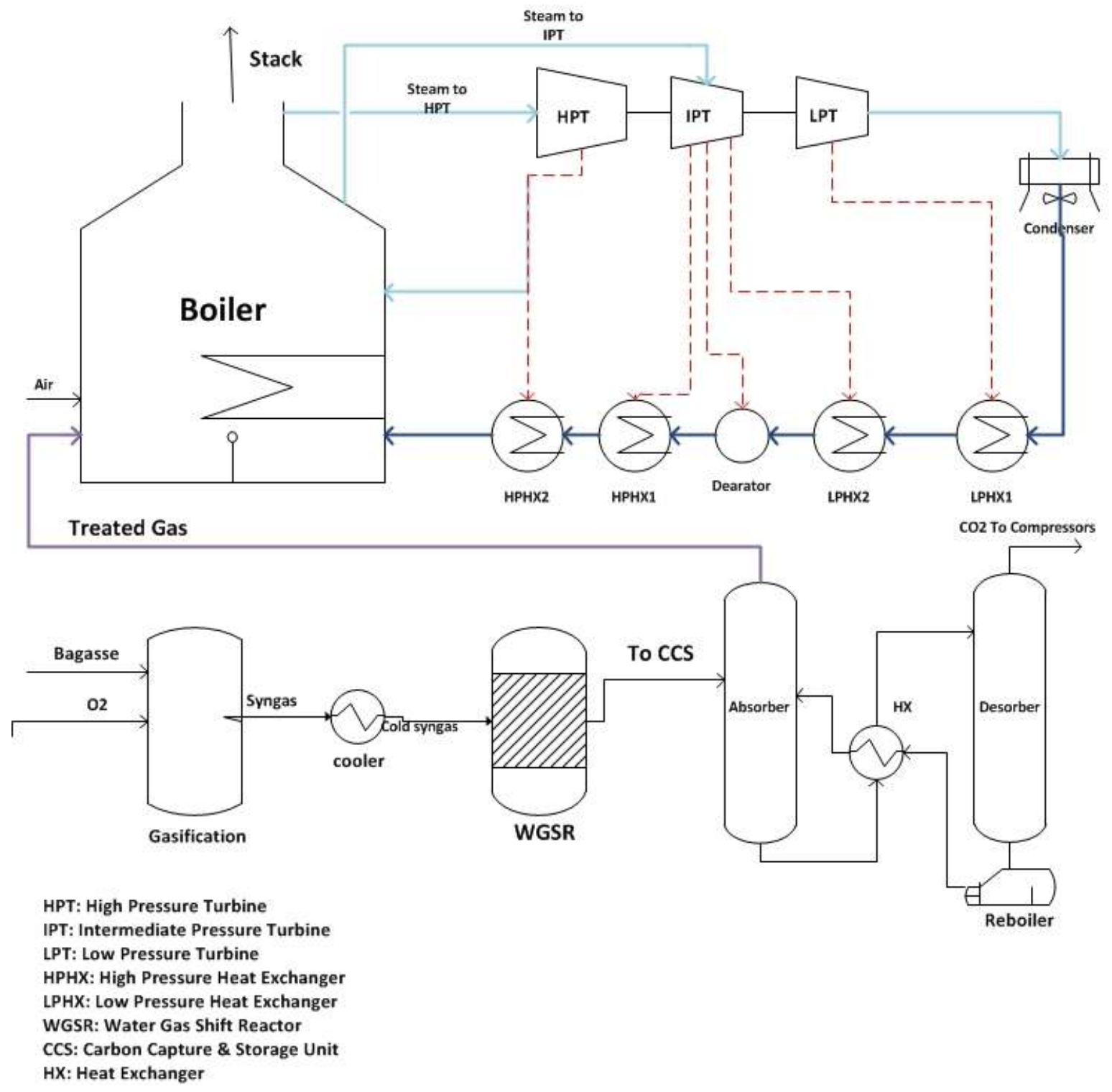

Fig. 3. Power plant with pre-combustion capture unit scheme 


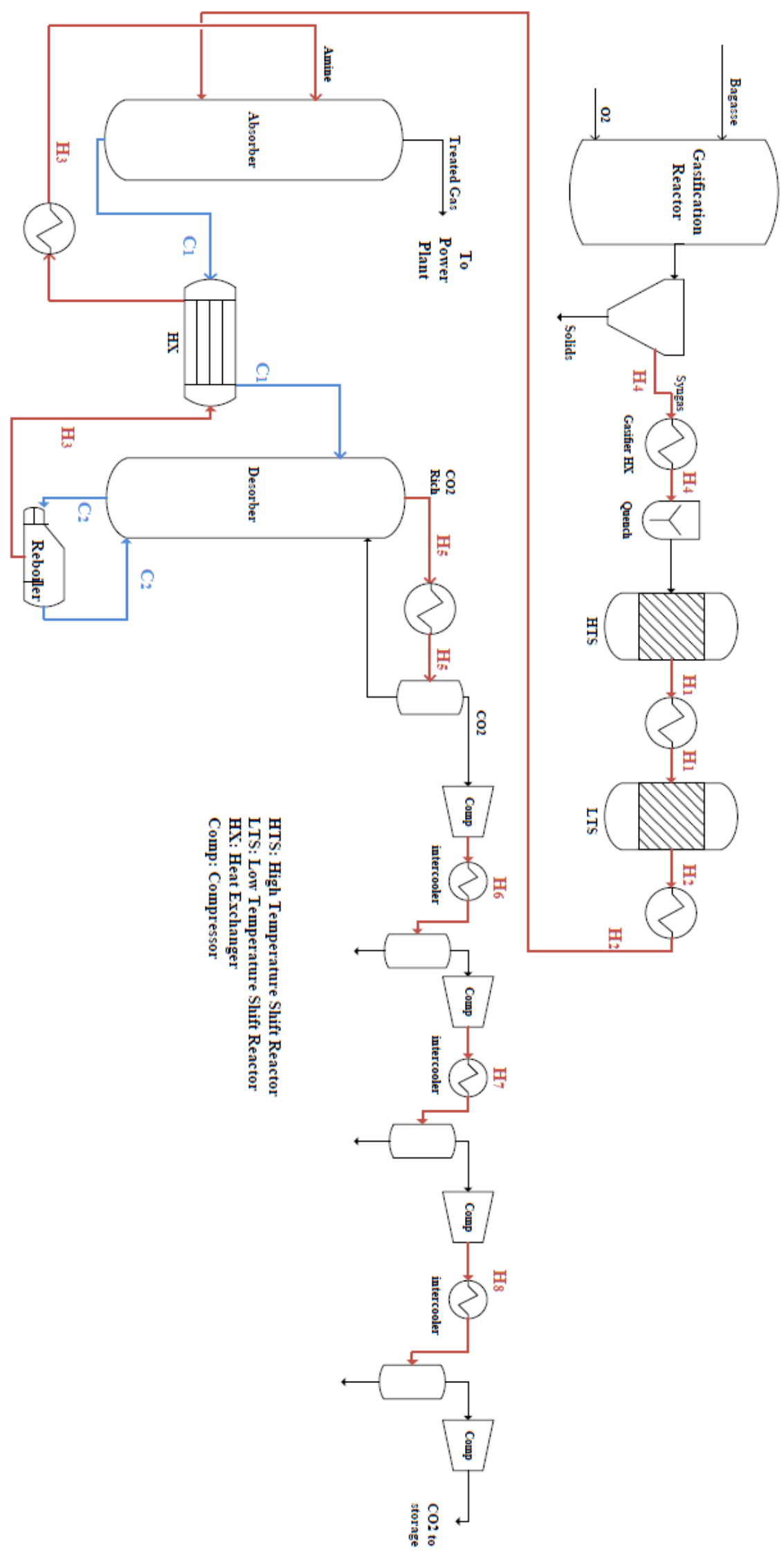

Fig. 4. Pre-combustion capture process 


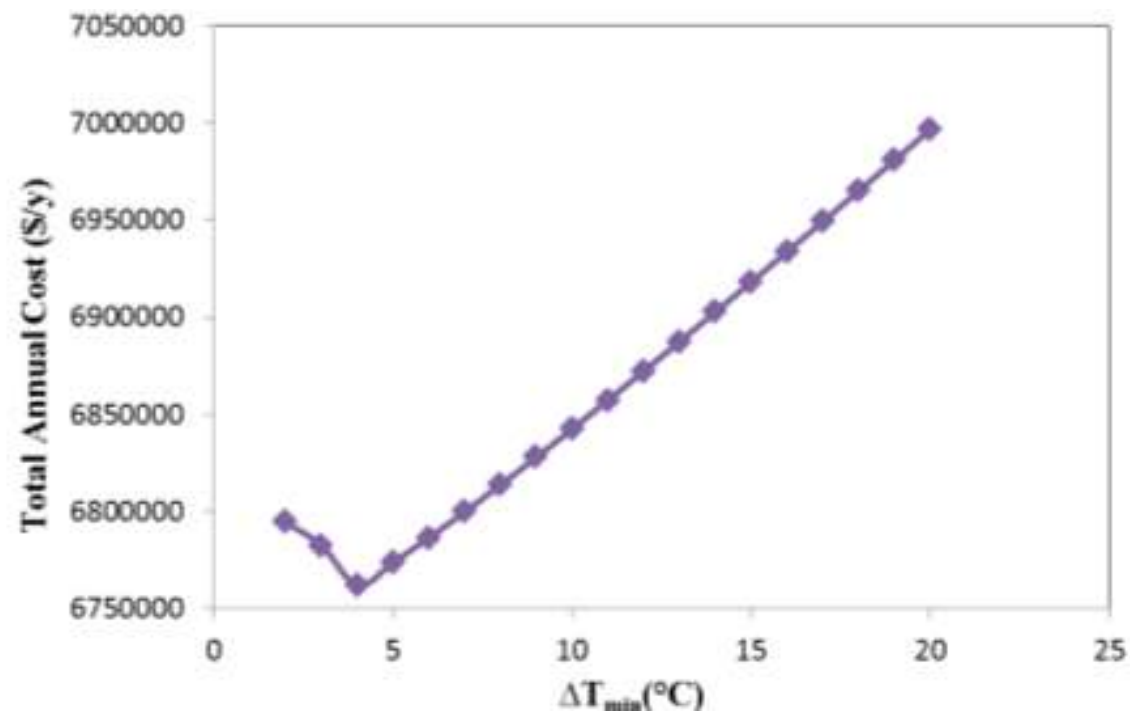

Fig. 5. Total annual costs versus different $\Delta \mathrm{T}_{\text {min }}$ 


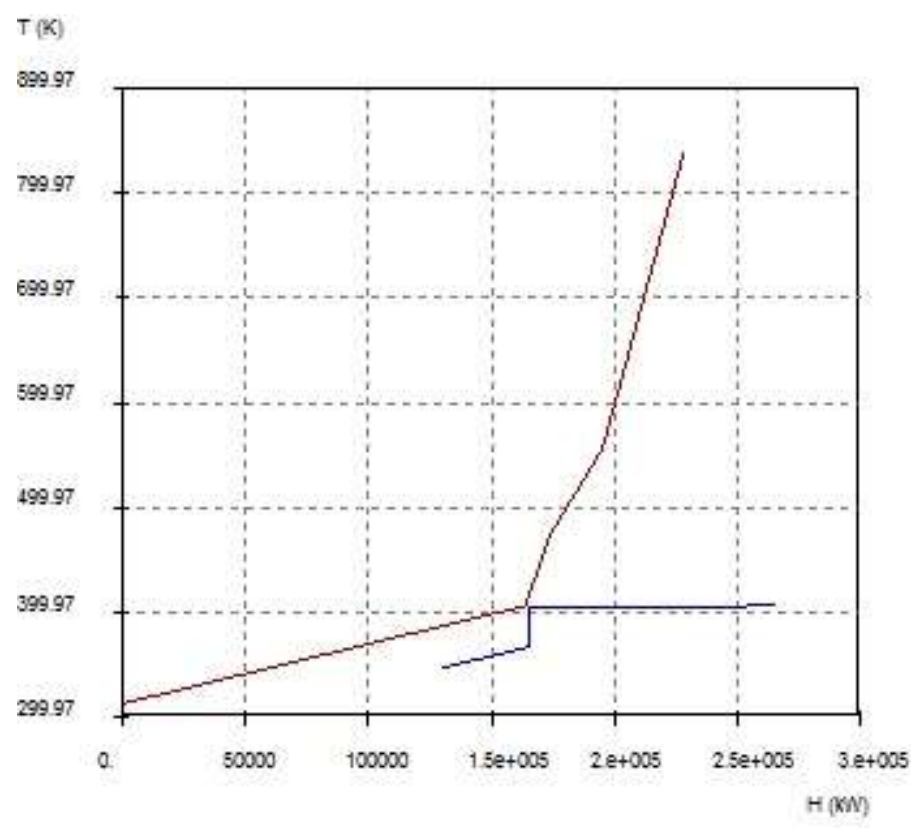

Composite Curves

a)

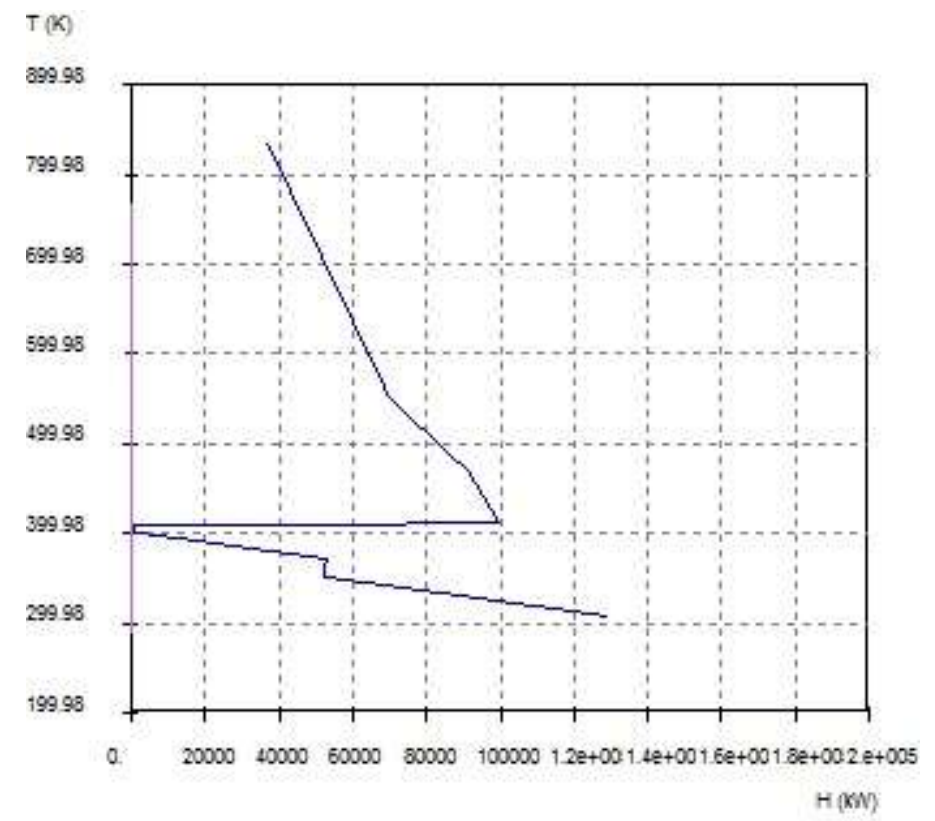

b) Grand Composite Curve

Fig. 6. a) Hot and Cold Composite Curve for pre-combustion capture process at $\Delta \mathrm{T}_{\min }=10{ }^{\circ} \mathrm{C}$

b) Grand Composite Curve for pre combustion capture process in $\Delta \mathrm{T}_{\min }=10{ }^{\circ} \mathrm{C}$ 


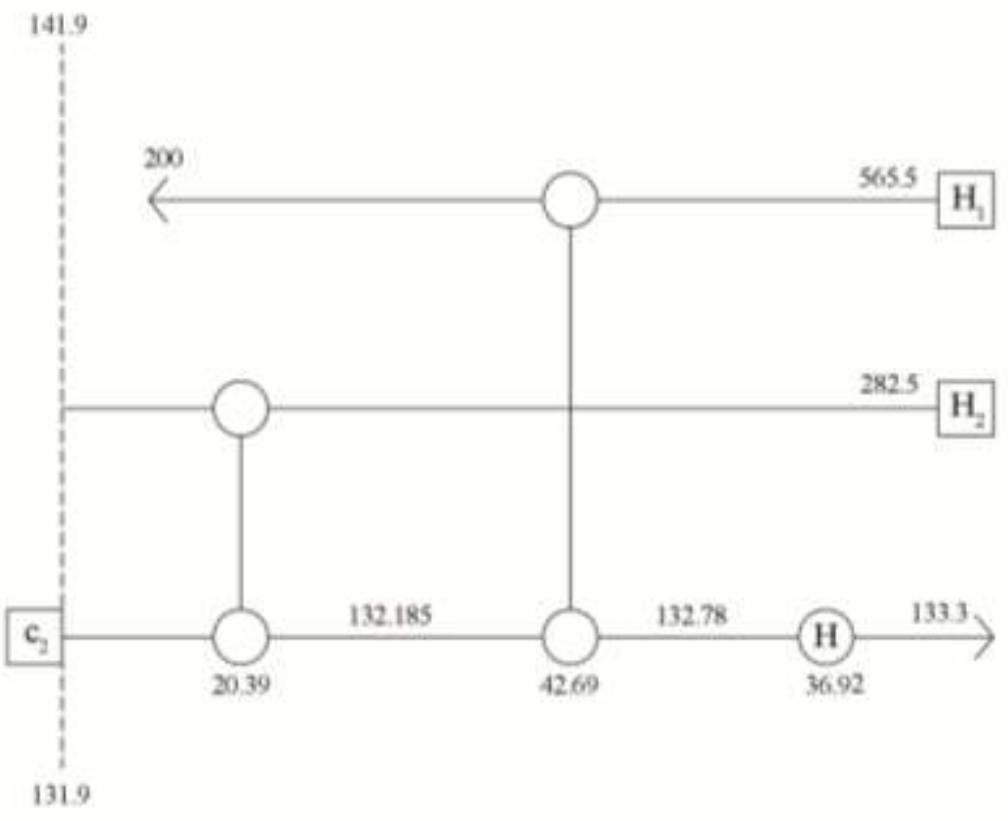

Fig. 7. HEN design for above the pinch section using PDM 


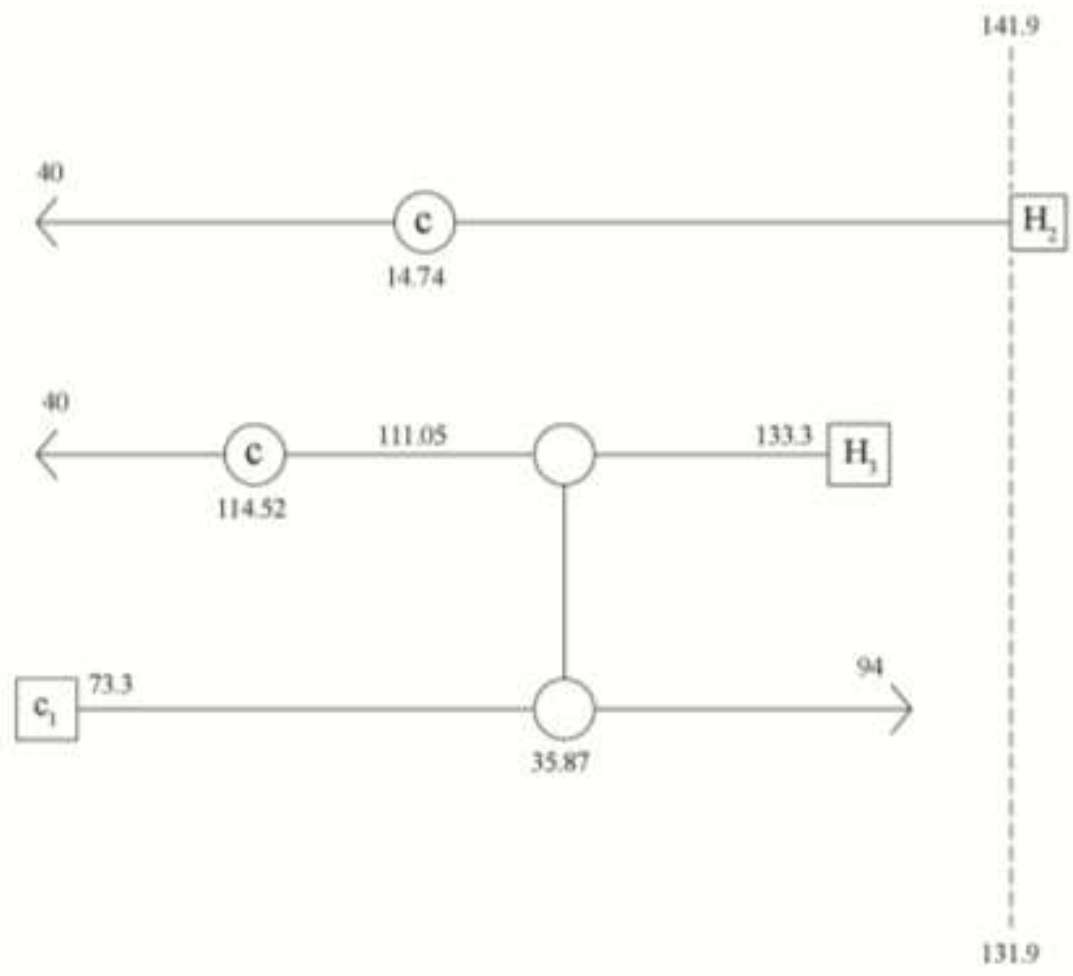

Fig. 8. HEN design for below the pinch section using PDM 


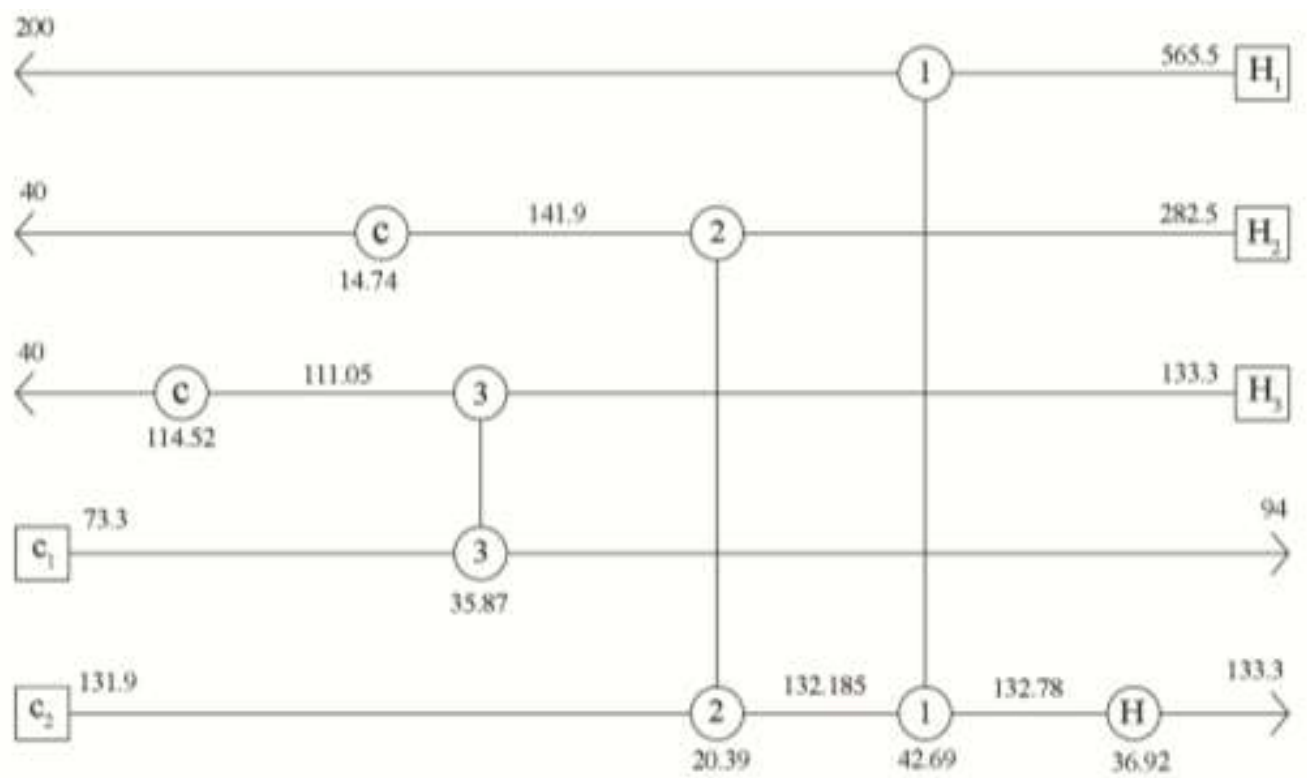

Fig. 9. Heat exchanger network design for pre-combustion capture process using PDM 


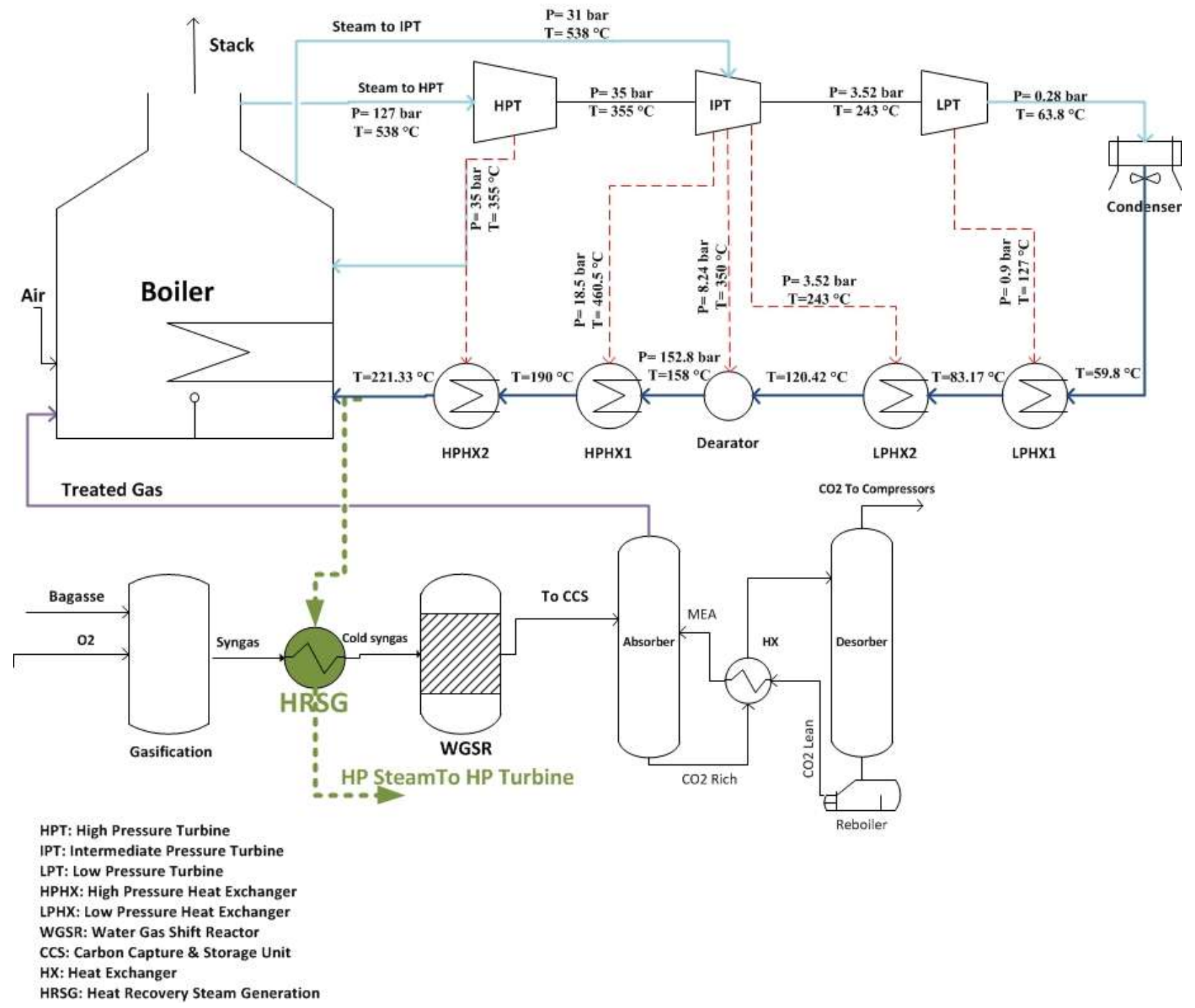

Fig. 10. HRSG unit in power plant 


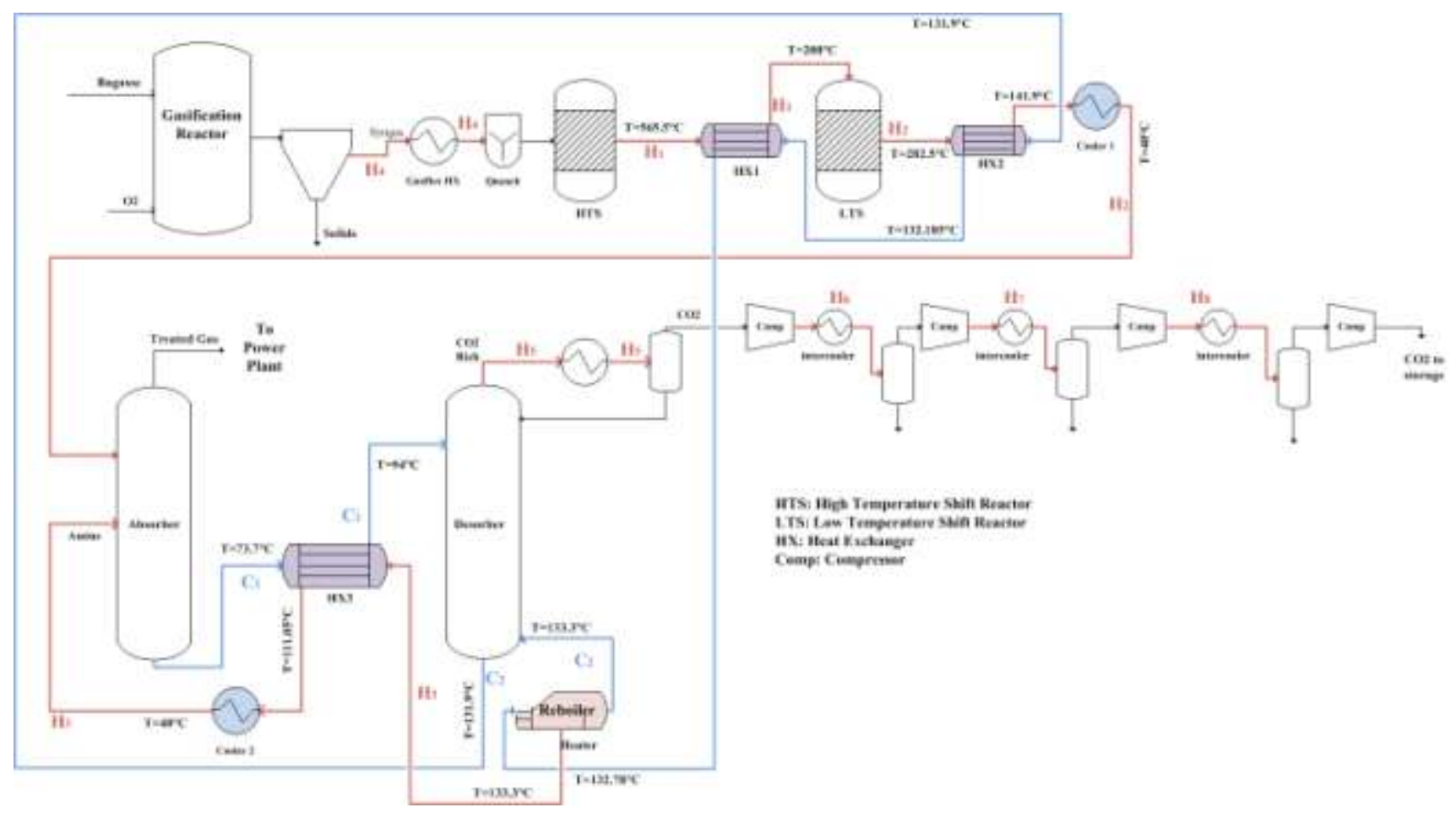

Fig. 11. Pre-combustion capture HEN optimization using Pinch Analysis 